\title{
Using Webqual 4.0 and Importance Performance Analysis to Evaluate E-Commerce Website
}

\author{
Johanes Fernandes Andry ${ }^{1)^{*}}$, Kevin Christianto ${ }^{2)}$, Fuji Rahayu Wilujeng ${ }^{3)}$ \\ 1)2)3) Universitas Bunda Mulia, Indonesia \\ Jl. Lodan Raya No. 2 Ancol, Jakarta Utara \\ 1)jandry@bundamulia.ac.id, ${ }^{2}$ kchristianto@bundamulia.ac.id, ${ }^{3)}$ fwilujeng@bundamulia.ac.id
}

Article history: Abstract

Received 12 September 2018 Revised 7 February 2019

Accepted 1 March 2019

Available online 28 April 2019

\section{Keywords: \\ E-Commerce \\ IPA \\ Lazada \\ Webqual 4.0 \\ Website}

\begin{abstract}
Background: The success of E-Business brings the highlight to websites as a tool to interact between company and customer. And recent studies indicate that quality of the website becomes something to be concern for company. Just like Huang pointed out that if company wants to build loyalty from their customer to get customer retention, one of much aspect that has to be noticed is the service quality from website.

Objective: This study examines quality of website, such as Lazada. Website that author used in this research, to see what quality that website has and what the importance of that quality has.

Methods: This study used Webqual 4.0 methodology to evaluate the website quality and see the importance of that quality using IPA (Importance Performance Analysis) to see how Lazada maintain that user expectations.

Results: From three dimension that Webqual 4.0 provide for this research and total of 124 students as sample this research, authors found that all of three has significance result to satisfied customer with specific aspect on facilities, menus and contents from the website. Conclusion: Average respondent from students Bunda Mulia University was satisfied with the facilities, menus and contents in the web both from the value of all respondents and each research variable. The existing results from website user can be used as feedback on evaluation and development of Lazada website to be more accommodating to the wishes and in accordance with the expectations of website users.
\end{abstract}

\section{INTRODUCTION}

The Internet Technology (IT) has brought major changes to the way business and marketing is conducted today. Many terms have been coined to represent the electronic concepts and applications such as e-marketing, EBusiness and E-Commerce [1]. Internet has some advantages not only for individual users but also for organizations, for example in terms of convenience, 24 hours access a day, 7 days a weeks, global reach, efficiency, alternative spaces and relatively unlimited choice, personalization, potential resources, and others. In a business context, internet brings impact of change that creates a new paradigm in business and commerce in form of digital marketing or internet marketing [2]. Nowadays, development of IT, especially in the field of the Internet increasingly unstoppable. Developments of this internet also influence the growth of online information media with the title of online media. The increasing growth of ecommerce and E-Business caused a decline in people's interest in traditional sales [3]. The Internet has become ubiquitous in the modern world. IT has become more commonplace, standardized and cheaper [4]. Today the internet is a flagship for the people businessman in an attempt to win the competition business and commerce. This is based on the increase in users internet in a world where the ease of the business to reach of market and develop business area [5]. One of the most popular internet-based services is the website [6]. The success of E-Business or E-Commerce initiatives of brick and mortar organizations primarily depends on the acceptance and adoption of information technology base products and services by customers [1,7]. According to Turban [8], E-Commerce is a transaction that occurs digitally or electronically $[8,9]$. E-Commerce is the result of application of IT, which allows transactions between producers and consumers via the internet. Transaction information through electronic is transactions made through the Internet network to provide business services, buying and selling goods, services and information between party rates [10]. An organization with a web site commerce that is difficult to use and interact with will project a poor image on the Internet and weaken the organizations position [11]. To improve and increase consumer loyalty; the business degree of companies has become a very important issue. Impacts of service quality on customer

\footnotetext{
${ }^{*}$ Corresponding Author
} 
satisfaction. Companies must maintain good service quality to create customer loyalty to effectively retain customers [12].

There are several methods related to webqual assessment, including the TAM method. Previous research by Deny and Andry [14] used the TAM method to provide input on factors that must be considered for the builders of social network applications. The study uses Facebook as the object of social networking chosen to see what factors should be considered for the builders of social network applications in Indonesia so that the social networking applications they create can be adopted by online store actors in Indonesia [13]. Another method for measuring e-learning success can use the model adopted by Delone \& Mclean as it was used in [14]to measure the success of e-learning systems at university in North Jakarta.

In this study to know are consumer satisfaction with webqual service. A good method used to determine the level of customer satisfaction with services is the SERVQUAL and Importance-Performance Analysis (IPA) methods. Wilujeng and Kusumo [15] used the SERVQUAL method to measure the satisfaction of an outsourced workforce with company services. Then proceed with the Importance-Performance Analysis (IPA) method to determine what attributes are good or which need to be improved in order to increase customer satisfaction [15].

Webqual is one of the methods or techniques of measuring website quality based on end user perception. This method is the development of SERVQUAL which is widely used previously in the measurement of service quality. Webqual has been developed since 1998 and has experienced several interactions in the preparation of dimensions and questions [16]. Webqual can be applied in evaluate IT services devoted to understand customer recognition and expectations, so that it can be taken into consideration improve the quality of the IT service [17].

Importance-Performance Analysis (IPA) is, in general, a method which provides a two dimensional importance-performance grid, where the values of importance and performance across diversified attributes are plotted against each other and the resulting importance performance space is generally divided into four quadrants [18]. The object of this research is web Lazada. The purpose of this study is to determine the effect of mobile applications to ease in transacting online and from applications that have been provided by the relevant ECommerce company. The benefit of this research is to make the result as a suggestion to improve the quality of service and to find out the attributes that affect customer satisfaction, what should be improved to maintain customer loyalty. The research was conducted by qualitative method, the result of the research with the result of interview to the student of Bunda Mulia University as the respondent.

\section{LITERATURE REVIEW}

\section{A. Importance Performance Analysis}

Fig.1, importance-performance analysis was introduced as a framework for understanding customer satisfaction as a function of both expectations related to salient attributes ("importance") and judgments about their performance ("performance"). While each yields valuable information independently, the full potential and promise of this type of information is more likely to be realized when the two concepts are merged [19]. Previous research used the IPA method as a tool to assess the feasibility of student work in Taiwan [20] and Measure the quality of services provided to surgical and medical inpatients at Kerman Medical Sciences University [21] [22].

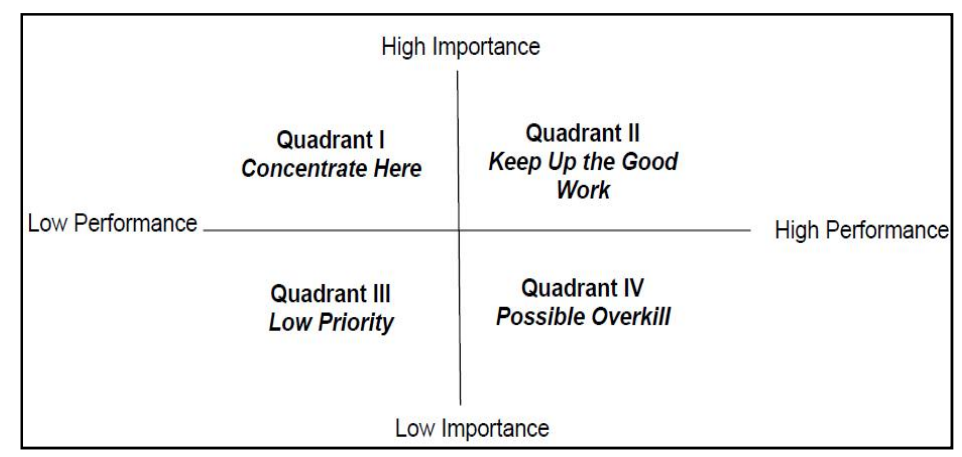

Fig.1 The Original IPA Framework [22].

\section{B. Webqual}

Quality website at this time is a strategic issue in interacting with the website [1]. Webqual is a method used to measure the quality of a website. Webqual sourced from a concept of Quality Function Deployment. QDF is a concept that is based on the voice of customer, which means Webqual formed based on user perceptions (end user) of a website [23]. Dimension of webqual 4.0 originated from many System Information Assessments, this means Webqual has a strong foundation such as user satisfaction model by Bailey. Here is a table questions from Webqual and sources support questions from Webqual 4.0 [15]. As described in Table 1, the standard Webqual 4.0 instrument contains 23 questions. 
TABLE 1

WEBQUAL 4.0 INSTRUMENTS [9, 20].

\begin{tabular}{cl}
\hline \hline Category & \multicolumn{1}{c}{ Questions } \\
\hline Usability: & Easy to learn to operate (UQ01) \\
& Interaction with the site is clear and understandable (UQ02) \\
& The site easy to navigate (UQ03) \\
& The site easy to use (UQ04) \\
& Attractive appearance (UQ05) \\
& Appropriate to the type of site (UQ06) \\
& Conveys a sense of competency (UQ07) \\
& Positive experience (UQ08) \\
& Provides accurate information (UQ09) \\
Information & Provides believable information (IQ10) \\
Quality: & Provides timely information (IQ11) \\
& Provides relevant information (IQ12) \\
& Easy to understand information (IQ13) \\
& Information at the right level of detail (IQ14) \\
& Information in appropriate format (IQ15) \\
& Good reputation (SI16) \\
Service & Safe to complete transactions (SI17) \\
Interaction: & Information feels secure (SI18) \\
& Sense of personalization (SI19) \\
& Sense of community (SI20) \\
& Communicate with the organization (SI21) \\
& Confident that goods/services will be delivered as promised (SI22) \\
& Overall view of the Web site (SI23)
\end{tabular}

\section{METHODS}

The methods used in this research are quantitative descriptive method. The purpose of this descriptive study to make the description, picture or painting in a systematic, factual, and accurate about the facts, properties and relationships between phenomena investigated. According to [24], it is stated that "in the study of quantitative data analysis using statistical data. Statistics that are used can be either descriptive statistics from inferential or inductive. Statistics inferential statistics can be parametric and non-parametric statistics".

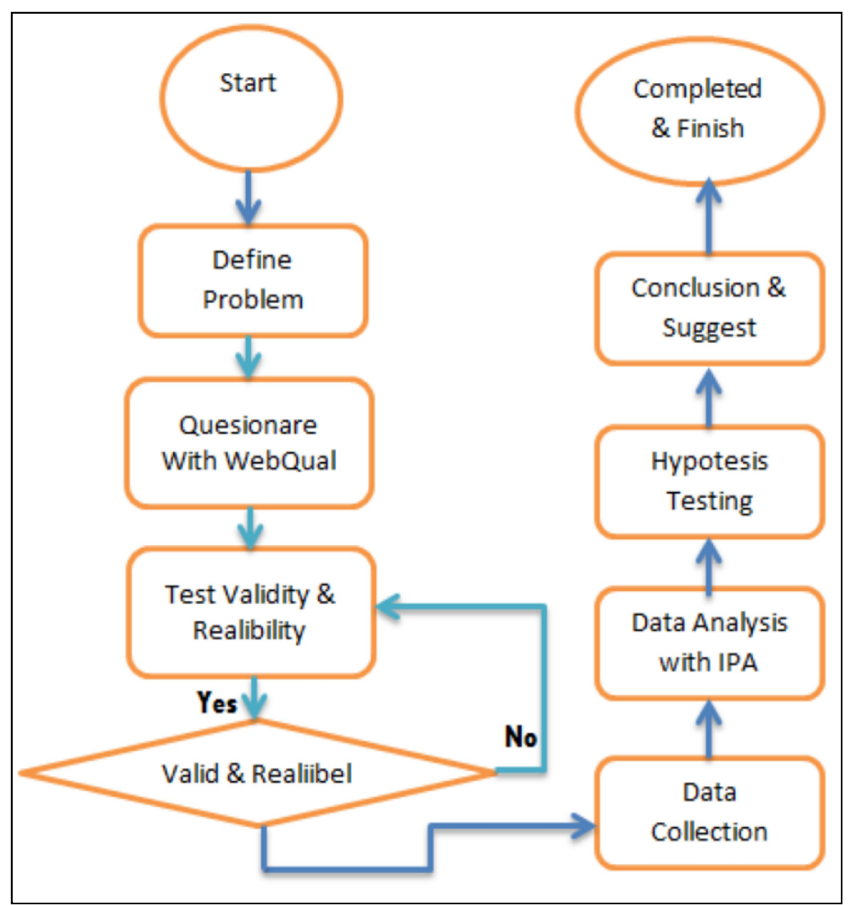

Fig.2 Research Thinking Framework [24]

In the context of research approach to use web-sites, one of the user web-site qualities identified in our research was "easy to find". A quality characteristic relevant to this user need might [7]. On fig. 2 researchers has 7 steps to do this research, and the detail is: 


\section{A. Questionnaire}

A number of written questions appropriate engineering approach Webqual used to obtain information from respondents about the things that are known or perceived. This questionnaire is intended to obtain information, in writing, of the respondent's interview and questionnaire of Bunda Mulia University as much as 124 students related to the research objectives.

\section{B. Instrument Research}

This research will be using Webqual technique to evaluate the website quality, approach which has been modified from previous research. That will have 3 dimensions and 23 attribute measurement quality service website. These attributes can be seen on Table 1.

\section{Testing Validity \& Reliability}

Validity and Reliability test is used to find out how big a level of truth of the process of collecting data that has been retrieved from the filling questionnaire by respondents, when it does not meet the standard reliable is valid and then data collection process will be repeated again and reliable is valid and fully tested until fulfilled.

\section{Collection and Selection Sample Data}

The sample selection techniques used in this research is Cluster Sampling because it analyses data from respondents in a population that has a characteristic or category from different sampling such as study program on Bunda Mulia University. With this technique, researchers got 124 respondents for the data analysis.

\section{E. Data Analysis (IPA)}

The data collected is then calculated an average based on the perceptions and expectations of each variable so that it will produce a mean value and level of compliance as well as the result of processing the data using SPSS, served into the Cartesian diagram with 4 quadrants of all variable, the diagram can be seen on Fig.1.

\section{F. Hypothesis Testing (t-test)}

To answer the truth results from analysis of Importance Performance Analysis (IPA) at once to answer the hypothesis of any dimension, then used the t test between the perceptions and expectations of the user to know GAP information system quality of service. The hypothesis that will be tested, such as:

$\mathrm{H} 1$ = There is significant difference between actual perceptions and expectations of respondent ideal dimensions of usability quality on the quality of service website Lazada is significant

$\mathrm{H} 2=$ There is significant difference between actual perceptions and expectations of respondent ideal dimensions of information quality on the quality of service website Lazada

$\mathrm{H} 3$ = There is significant difference between actual perceptions and expectations of respondent ideal dimensions of service interactive on the quality of service website Lazada.

\section{RESULTS}

\section{A. Validity}

One important step that must be done in a study is to test the validity of the data, so it can be known whether the data have been obtained is data that can describe the actual situation or in accordance with the reality that occurred, so that the data is worthy to be researched further and can used to measure the object under study.

The questionnaire that has been distributed to 124 respondents who are the users of Lazada, tested the validity by performing a comparison between $r$ calculate and $r$ table where the $r$ table value obtained from the $r$ product moment table with the significance level of $1 \%$ with $n=124$, that can be seen on Table 2 . The $r$ table value for $\mathrm{Df}=122(\mathrm{Df}=\mathrm{n}-2)$ is 0.2287 . If $\mathrm{r}$ calculate $>\mathrm{r}$ table, then the question item of the questionnaire is valid. On the contrary if $r$ calculate $<r$ table then the question items of the questionnaire is not valid. Therefore, each item in question of the service attribute assessed should have a value above 0.2287 in order to be valid.

\section{B. Reliability}

Reliable data is data that shows the consistency and stability of each attribute under study. For that done the data reliability test to be known whether the data collected is data that is free from random error variance. Test reliability on table 3 of this research using coefficient Cronbach Alpha. Based on the values obtained from each service attribute on the level of actual and level of expectation, where all items have value Cronbach Alpha above 0.5 then each item of question that has been disseminated can be said reliable for researcher to proceed to the next step. 


\section{Hypothesis Testing}

The test technique in testing a hypothesis using Paired Samples t-Test hypothesis test in which the respective dimensions according to Webqual: Usability Quality, Information Quality and Service Interactive on Table 4. And the result of dimension usability quality, that difference between value mean to perform is 31.71 and expectation is 35.78. Results the calculation of $\mathrm{T}$ statistics show the value of -8.118 and significance from 0000 . Because of the significance of the results of $0000<0.05$ then concluded that the difference between actual perceptions and expectations of respondent ideal dimensions of usability quality on the quality of service website Lazada is significant and the accepted hypothesis $\left(\mathrm{H}_{1}\right)$ while $\mathrm{H}_{0}$ is rejected.

TABLE 2

WEBQUAL 4.0 VARIABEL VALIDITY

\begin{tabular}{ccccc}
\hline \hline Attribute & $\begin{array}{c}\text { R Count } \\
\text { Actual }\end{array}$ & $\begin{array}{c}\text { Description } \\
\text { Actual }\end{array}$ & $\begin{array}{c}\text { R Count } \\
\text { Expect }\end{array}$ & $\begin{array}{r}\text { Description } \\
\text { Expect }\end{array}$ \\
\hline UQ01 & 0.665 & VALID & 0.525 & VALID \\
UQ02 & 0.567 & VALID & 0.620 & VALID \\
UQ03 & 0.564 & VALID & 0.535 & VALID \\
UQ04 & 0.566 & VALID & 0.410 & VALID \\
UQ05 & 0.671 & VALID & 0.479 & VALID \\
UQ06 & 0.495 & VALID & 0.463 & VALID \\
UQ07 & 0.541 & VALID & 0.462 & VALID \\
UQ08 & 0.568 & VALID & 0.525 & VALID \\
UQ09 & 0.463 & VALID & 0.494 & VALID \\
IQ10 & 0.648 & VALID & 0.622 & VALID \\
IQ11 & 0.692 & VALID & 0.556 & VALID \\
IQ12 & 0.733 & VALID & 0.663 & VALID \\
IQ13 & 0.671 & VALID & 0.615 & VALID \\
IQ14 & 0.550 & VALID & 0.520 & VALID \\
IQ15 & 0.442 & VALID & 0.466 & VALID \\
SI16 & 0.803 & VALID & 0.572 & VALID \\
SI17 & 0.756 & VALID & 0.611 & VALID \\
SI18 & 0.764 & VALID & 0.498 & VALID \\
SI19 & 0.727 & VALID & 0.510 & VALID \\
SI20 & 0.690 & VALID & 0.456 & VALID \\
SI21 & 0.725 & VALID & 0.533 & VALID \\
SI22 & 0.773 & VALID & 0.566 & VALID \\
SI23 & 0.727 & VALID & 0.641 & VALID \\
\hline
\end{tabular}

Dimension information quality, which difference between values mean to perform is 20.65 and expectation is 23.33. Results the calculation of $T$ statistics show the value of -7.070 and significance from 0000 . Because of the significance of the results of $0000<0.05$ then concluded that the difference between actual perceptions and expectations of respondent ideal dimensions of information quality on the quality of service website Lazada is significant and the accepted hypothesis (H2) while $\mathrm{H} 0$ is rejected.

TABLE 3

WEBQUAL 4.0 VARIABEL RELIABILITY

\begin{tabular}{ccccc}
\hline \hline Attribute & $\begin{array}{c}\text { Cronbach's } \\
\text { alpha Actual }\end{array}$ & $\begin{array}{c}\text { Description } \\
\text { Actual }\end{array}$ & $\begin{array}{c}\text { Cronbach's } \\
\text { alpha Expect }\end{array}$ & $\begin{array}{c}\text { Description } \\
\text { Expect }\end{array}$ \\
\hline UQ & 0.736 & RELIABLE & 0.776 & RELIABLE \\
UQ & 0.678 & RELIABLE & 0.595 & RELIABLE \\
SI & 0.885 & RELIABLE & 0.669 & RELIABLE \\
\hline
\end{tabular}

Dimension service interactive, that difference between value mean to perform is 29.30 and expectation is 31.91 . Results the calculation of $\mathrm{T}$ statistics show the value of -5.340 and significance from 0000 . Because of the significance of the results of $0000<0.05$ then concluded that the difference between actual perceptions and expectations of respondent ideal dimensions of service interactive on the quality of service website Lazada is significant and the accepted hypothesis (H3) while $\mathrm{H} 0$ is rejected.

TABLE 4

MEAN AND T TEST (WITH N=124)

\begin{tabular}{ccccccc}
\hline \hline & Perception & Mean & T & Std Deviation & $\begin{array}{c}\text { Std. Error } \\
\text { Mean }\end{array}$ & $\begin{array}{c}\text { Sig } \\
\end{array}$ \\
& Perform & 31.71 & & 4.569 & 0.410 & \\
\hline Usability Quality & Expectation & 35.78 & -8.118 & 3.973 & 0.357 & 0.0000 \\
& Perform & 20.65 & & 3.609 & 0.324 & 0.0000 \\
Information Quality & Expectation & 23.33 & -7.070 & 3.118 & 0.280 & 0.488 \\
& Perform & 29.30 & & 5.435 & 0.340 & 0.0000 \\
\hline
\end{tabular}




\section{Calculation of the Average Actual Levels and Expectations}

Webqual measurement based on weighting of values multiplied by the results of the calculation of respondents' answers on each attribute in the questionnaire that describes the level of expectations and actual felt by the customer that offered by Lazada is shown by Table 5. From Table 5, it can be concluded that the value of customer actual is still below the value of interest that customers expect. Based on the table, Webqual calculation can be done through comparison of importance and customer satisfaction by performing Gap Score calculation from respective attributes of E-Commerce web quality as judged on Lazada.

TABLE 5

WEBQUAL 4.0 CALCULATION RESULT

\begin{tabular}{|c|c|c|c|c|c|}
\hline ， & Performance (Xi) & Expectations (Yi) & $\begin{array}{c}\text { Performance }(\mathbf{X i}) \\
\text { Mean }\end{array}$ & $\begin{array}{c}\text { Expectations (Yi) } \\
\text { Mean }\end{array}$ & Gap \\
\hline & Score Total & Score Total & Score Total & Score Total & \\
\hline UQ01 & 435 & 493 & 3.51 & 3.98 & -0.47 \\
\hline UQ02 & 444 & 505 & 3.58 & 4.07 & -0.49 \\
\hline UQ03 & 439 & 487 & 3.54 & 3.93 & -0.39 \\
\hline UQ04 & 435 & 485 & 3.51 & 3.91 & -0.40 \\
\hline UQ05 & 443 & 505 & 3.57 & 4.07 & -0.50 \\
\hline UQ06 & 432 & 491 & 3.48 & 3.96 & -0.48 \\
\hline UQ07 & 438 & 488 & 3.53 & 3.94 & -0.40 \\
\hline UQ08 & 436 & 503 & 3.52 & 4.06 & -0.54 \\
\hline UQ09 & 430 & 480 & 3.47 & 3.87 & -0.40 \\
\hline IQ10 & 431 & 485 & 3.48 & 3.91 & -0.44 \\
\hline IQ11 & 437 & 492 & 3.52 & 3.97 & -0.44 \\
\hline IQ12 & 426 & 457 & 3.44 & 3.69 & -0.25 \\
\hline IQ13 & 418 & 488 & 3.37 & 3.94 & -0.56 \\
\hline IQ14 & 426 & 491 & 3.44 & 3.96 & -0.52 \\
\hline IQ15 & 422 & 480 & 3.40 & 3.87 & -0.47 \\
\hline SI16 & 449 & 491 & 3.62 & 3.96 & -0.34 \\
\hline SI17 & 454 & 495 & 3.66 & 3.99 & -0.33 \\
\hline SI18 & 464 & 478 & 3.74 & 3.85 & -0.11 \\
\hline SI19 & 462 & 510 & 3.73 & 4.11 & -0.39 \\
\hline SI20 & 458 & 487 & 3.69 & 3.93 & -0.23 \\
\hline SI21 & 449 & 509 & 3.62 & 4.10 & -0.48 \\
\hline SI22 & 441 & 503 & 3.56 & 4.06 & -0.50 \\
\hline SI23 & 456 & 484 & 3.68 & 3.90 & -0.23 \\
\hline Average & 440.22 & 490.74 & 3.55 & 3.96 & -0.41 \\
\hline
\end{tabular}

If analysed based on each service attribute assessed, there are some attributes that have a gap score that is still relatively moderate high. The attributes that are categorized into the high gap score are the attributes that have a gap score above the average. The average score gap score obtained from the average difference between the actual value perceived by the customer and the expected interest value of each attribute is worth -0.41 . Therefore, special attention from the company to attributes that have a gap score is considered high or higher than average score, because it indicates the existence of customer dissatisfaction, due to lack of fulfilment of customer expectations on the actual of current attributes, so that needed improvement to increase customer satisfaction value.

\section{E. Distribution Attribute Analysis}

The result of the level between perform with exact, then continued by analysing the distribution of attributes in a Cartesian diagram result with SPSS software. The Importance Performance Analysis (IPA) method is used to rank the interests and performance of various attributes of a service collection and identify actions that need improvement the result of the Cartesian diagram gives an overview with Importance Performance Analysis which enter into four quadrants, the result details explain at discussion.

\section{DISCUSSION}

In the Importance-Performance Analysis, mapping was carried out into 4 quadrants for all attributes affecting quality website. The result distribution of quadrants in the Importance-Performance Analysis can be seen in Fig. 3. The following is an explanation of the quadrant division in the Cartesian or IPA diagram:

\section{A. The First Quadrant (Concentrate Here)}

The first quadrant is between the high expected lines and low performance lines. This quadrant is describes the factors that are considered gives satisfaction to what is expected of users and quality services of Lazada website as a supporting factor in meeting user expectations. The following attributes result in first quadrants is Easy to 
learn to operate (UQ01), Appropriate to the type of site (UQ06), Positive experience (UQ08), Provides timely information (IQ11), and Information at the right level of detail (IQ14).

\section{B. The Second Quadrant (Keep up the Good Work)}

The second quadrant is between the high expected lines and high performance lines. This quadrant describes the factors that are considered not too important and less expected users, but has a good performance. It contains the attributes of the second quadrant is Interaction with the site is clear and understandable (UQ02), Attractive appearance (UQ05), Good reputation (SI16), Safe to complete transactions (SI17), Sense of personalization (SI19), Communicate with the organization (SI21), and Confident that goods/services will be delivered as promised (SI22).

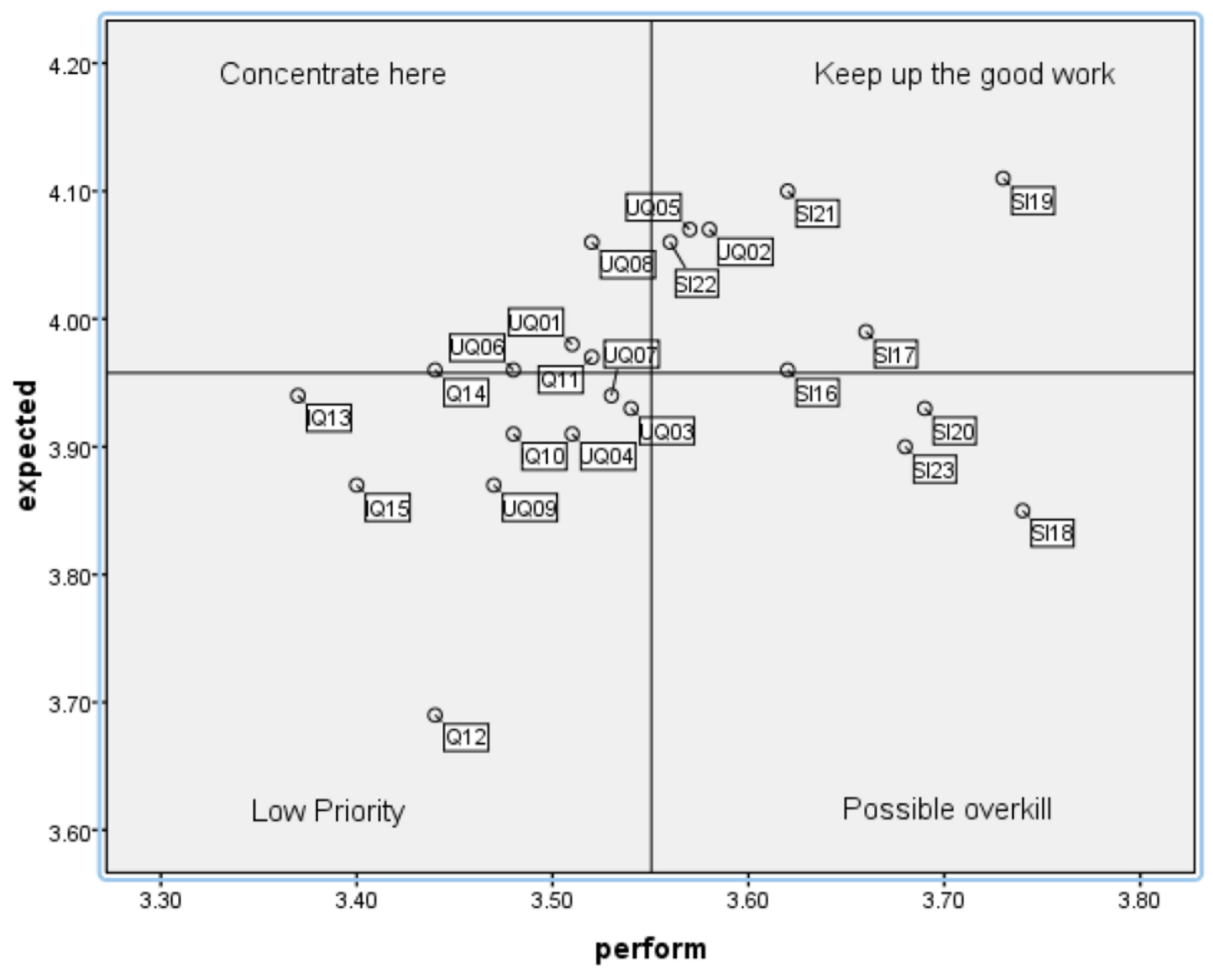

Fig.3. Cartesian Diagram Result of Distribution Attribut

\section{The Third Quadrant (Low Priority)}

The third quadrant is between the low expected lines and low performance lines. This quadrant describes a relatively low performance. The factors that are considered not too important and less expected users. The following attributes that are included into the third quadrant is The site easy to navigate (UQ03), The site easy to use (UQ04), Conveys a sense of competency (UQ07), Provides accurate information (UQ09), Provides believable information (IQ10), Provides relevant information (IQ12), Easy to understand information (IQ13), and Information in appropriate format (IQ15).

\section{The Fourth Quadrant (Possible Overkill)}

The fourth quadrant is between the low expected lines and high performance lines. However the performance of information systems has not been giving satisfaction to what is expected of users are optimal, in this quadrant describes the factors which are considered very important and expected user. The attributes that are included into the Fourth Quadrant is Information feels secure (SI18), Sense of community (SI20), Overall view of the Web site (SI23).

In this study, the attributes belong to the quadrant Concentrate. These are considered to be a priority for improvement. The existence of this attribute is considered very important for employees but the employee feels very dissatisfied with the services provided. Companies must make improvements to these attributes in order to increase satisfaction and trust. The attributes included in the Concentrate These quadrant include Easy to learn to operate (UQ01), appropriate type of site (UQ06), Positive experience (UQ08), timely information provision (IQ11), and Information at the right level of detail (IQ14). Some are dominated by usability quality and information quality variables. This is in line with the results of research conducted by Hermanto et all [16] which says that user satisfaction has the greatest impact on reusability. The results of these studies significantly indicate that there are objective and subjective aspects that affect the reusability of the web-based service system. 
Based on this, it can be said that there is indeed dissatisfaction with customers of Lazada E-Commerce website users due to low usability quality. It can also be used by Lazada's E-Commerce website in order to evaluate the usability of the service system in order to increase consumer satisfaction of Lazada E-Commerce website users.

The results obtained from this research are the application Lazada is good in supporting online transactions. However, it would be better if in the future Lazada improve the quality of service in its mobile commerce applications by adding "Last Viewed" feature, so customers can view the last item without searching again for the item. In addition, it would be better if in the future Lazada provide delivery service "Same Day Service" where the goods can be delivered on the same day by ordering goods and adding balance features that allow customers to pay for goods without having to transfer, all they need to do is fill the balance [10].

\section{CONCLUSIONS}

The analysis result of website E-Commerce Lazada using Webqual focuses on Usability, Information Quality and Service Interaction showed that average respondent form students Bunda Mulia University was satisfied with the facilities, menus and contents in the web both from the value of all respondents and each research variable. The existing results from website user can be used as feedback on evaluation and development of Lazada website to be more accommodating to the wishes and in accordance with the expectations of website users. For future research when collection of data can use smartphone applications such as Android to speed up time and save costs. This research has limitations that the respondent populated from Bunda Mulia University, so this result does not describe as the whole North Jakarta region.

\section{REFERENCES}

[1] J.F. Andry , J. Loisa, “The E-Commerce Potential for Home-Based Businesses: A Case Study,” Jurnal Ilmiah Fifo, VIII, 2, 2016, pp.2327.

[2] B.C. Shia, M. Chen, A.D. Ramdansyah, S.Wang,"Measuring Customer Satisfaction toward Localization Website by Webqual and Importance Performance Analysis (Case Study on AliexPress Site in Indonesia )," American Journal of Industrial and Business Management, 6, 2016, pp. 117-128.

[3] E.E. Barus, Suprapto, A.D Herlambang,"Analisis Kualitas Website Tribunnews.com Menggunakan Metode Webqual dan Importance Performance Analysis," Jurnal Pengembangan Teknologi Informasi dan Ilmu Komputer, 2, 4, 2018, pp. 1483-1491.

[4] N. Elangovan, "Evaluating Perceived Quality of B-School Websites," Journal of Business and Management. 12, 1, 2013, pp. 92-102.

[5] W. Sastika,"Analisis Pengaruh Kualitas Website (Webqual 4.0) Terhadap Keputusan Pembelian Pada Website E-Commerce Traveloka," Sentika, 2016, pp. 649-657.

[6] H. Medyawati, Farida, E. Hegarini,“Model Pengukuran Kualitas Layanan Website E-Banking Di Indonesia,” SNATI, 2012, pp.A23A28.

[7] S. Barnes, R. Vidgen,“Webqual: An Exploration of Web-site Quality,” Communications. 1, 2000, pp. $298-305$.

[8] E. Turban, L. Volonino, E. McLean, J. Wetherbe, "Information Technology for Management” Transforming Business in the Digital Economy 3rd Edition, United States of America: John Wiley \& Sons Inc, 2001.

[9] K. Christianto, "Hubungan Dimensi Service Quality Dengan Kualitas Layanan E-Commerce Dari Sudut Pandang Konsumen Online," Jurnal Teknologi Informasi, Volume 12, Nomor 2, Agustus 2016, pp. 15-21.

[10] V. Octavianus, K. Wijaya, Fenny, J.F Andry,"Effect of Mobile E-Commerce Application on Easing Online Transactions," Jurnal Ilmiah Teknologi dan Informasi, 6, 2, 2017, pp. 80-84.

[11] S.J. Barnes, R.T. Vidgen, “An Integrative Approach To the Assessment of E-Commerce Quality,” Journal of Electronic Commerce Research, 3, 3, 2002, pp. 114-127.

[12] G.H. Tzeng,H.F. Chang, “Applying Importance-Performance Analysis as a Service Quality Measure in Food Service Industry,” Journal of Technology Management \& Innovation, 6, 3, 2011, pp. 106-115.

[13] Deny, J.F.Andry," Faktor Penentupenggunaan Facebook Oleh Toko Online Menggunakan Model TAM," Seminar Nasional Teknologi Informasi 2017, Universitas Tarumanagara, pp. 64-71.

[14] Deny, J.F.Andry, "Pengukuran Keberhasilan E-Learning dengan Mengadopsi Model Delone \& Mclean," Jurnal Sistem Informasi dan Bisnis, Vol.8, No.1, 2018, pp. 68-75.

[15] F. R. Wilujeng, R. Kusumo, “Analisis Kepuasan Tenaga Kerja Outsourcing Terhadap Pelayanan Perusahaan Dengan Metode Importance Performance Analysis (IPA)," Journal of Industrial Engineering and Management Systems, 2018, Vol. 11, No. 2, 64-69

[16] A. Hermanto, Supangat, F. Mandita, "Evaluasi Usability Layanan Sistem Informasi Akademik Berdasarkan Kombinasi SerQual dan Webqual", Journal of Information Systems Engineering and Business Intelligence, Vol.3, No. 1, 2017, pp. 33-39.

[17] Z.F.S Putra, M. Sholeh, N. Widyastuti,“Analisis Kualitas Layanan Website BTKP-DIY Menggunakan Metode Webqual 4.0,” Jurnal JARKOM 1, 2, 2014, pp. 174-184.

[18] K.Y. Wong,"Critical success factors for implementing knowledge management in small and medium enterprises," Industrial Management \& Data Systems, 105, 3, 2005, pp. 261-279.

[19] Y. C. Chen, “Applying importanceperformance analysis to assess student employability in Taiwan,” Journal of Applied Research in Higher Education, Vol. 10, No. 1, 2018, pp. 76-86.

[20] A. Izadi, "Evaluating health service quality: using importance performance analysis," International Journal of Health Care Quality Assurance, Vol. 30, No. 7, 2017, pp. 656-663.

[21] C.H. Wu, Y.C. Lee, Y.C Cheng, S.B Tasi, "The use of importance-performance analysis (IPA) in evaluating bank services," Conference Service Systems and Service Management (ICSSSM), 6, 2, 2012, pp. 654-657. 
[22] Sujono, H.B.Santoso, "E-Learning Quality Analysis Of Use Of Web Conference In The Improvement Of Students With Learning Method Webqual (Case Study: Universitas KH . A . Wahab Hasbullah )," International Journal of Science and Technology, 6, 1, 2017, pp. 814.

[23] W. Gata, H.O. Gilang, “Analysis of information system quality of service on BSI Academy's environment using webqual methods, importance performance analysis and fishbone," Journal of Theoretical and Applied Information Technology, 95, 2, 2017, pp. $229-241$.

[24] Sugiyono, Memahami Penelitian Kualitatif, 2012. 